\title{
Plastic Pollution: A Global Problem from a Local Perspective
}

\author{
Joystu Dutta ${ }^{*}$ and Moharana Choudhury ${ }^{2}$ \\ ${ }^{1}$ Department of Environmental Science, Sarguja University, India \\ ${ }^{2}$ Department of Environmental Science, Tezpur University, India
}

*Corresponding author: Joystu Dutta, Department of Environmental Science, Sarguja

University, Ambikapur (CG.)-497001, India, Tel: +91 7049804500; Email: joystu.dutta@gmail.com

\section{Editorial \\ Volume 1 Issue 1}

Received Date: August 07, 2018

Published Date: August 13, 2018

DOI: $10.23880 /$ oajwx-16000102

\section{Editorial}

Plastic is a necessary evil of current times. It is ubiquitous in modern time's cape, from polythene bags for daily shopping to PVC pipes, from kitchenware to pet bottles; plastic and its associated derivatives lands up everywhere. However, poor management of plastic waste is burying us in every corner of our blue planet right from the shores of Arabian Sea to the tropical paradise of Hawaii and the Pacific Islands, from mighty Himalayas to the Great Barrier Reef along the coasts of Australia. Our collective awareness for various negative impacts of plastic pollution is increasing in comparison to the bygone decade and slowly there is a mindset transition regarding rampant plastic usage. The central themes of this year's Earth Day and World Environment Day are based on beating plastic pollution across the globe. Recent case studies and newspaper reports indicate the fact of deleterious effects of plastic pollution. A team from Clean Oceans International went for massive cleanup in Alaskan coastline only to be taken aback by the humongous quantities of plastic wastes that float ashore. Alaska's rugged yet fragile coastlines are particularly vulnerable because of the dynamics of the Pacific Ocean's circulation patterns. A patch of plastic garbage in the Pacific Ocean amounts to twice the size of Texas, a New Study Says. Plastic bags have been the principal cause behind the deaths of the sperm whales in the Mediterranean since few years. A report by scientists studying the stomach content of Laysan Albatross chicks on Midway Atoll in the Pacific Ocean revealed some eye opening observations. Forty percent of Laysan Albatross chicks die before fledgling. The chick abdomen is found to be filled with plastic trash. Coral reefs entangled with plastic are twenty times more diseased and vulnerable; a new study reports. These are the victims of our remorseless progress. Legendary broadcaster and naturalist Sir David Attenborough discusses the grave issue during the portrayal of groundbreaking documentary, 'Our Blue
Planet'. More than eight million tones of plastic reach the sea every year. There will be more plastic than fish in the sea by the year 2050 and 99 per cent of the planet's seabirds will have eaten some. The average person who eats seafood swallows up to 11,000 pieces of micro plastic every year, according to a study by researchers at the University of Ghent. As Prince Charles puts it at a recent Our Ocean summit, "Plastic is very much on the menu". Our rivers are shrinking and floodplains are choked with plastic wastes. Mighty rivers of India are choked by hundreds and thousands of quintals of plastic waste. From Barak valley in Assam to river beds along the Ganges, from Himalayan valleys up north to the mighty rain fed rivers in the South, we are facing the crisis upfront. A 'Swachha Bharat Abhiyaan' and 'Namami Gange' initiative introduced by Government of India is soulfully dedicated to bring out sustainable solutions to this burning issue. In this critical juncture, it is the duty of all budding environmentalists to create mega awareness across different societal levels to address the issue of plastic pollution. Strict rules, laws and regulations are in place but what lack is the implementation. India has banned all forms of disposable plastic in New Delhi and surrounding NCR but such measures do not attain sustainability due to lack of public awareness and administrative carelessness. India generates 5.6 million tones of plastic waste annually, and the country accounts for $60 \%$ of plastic waste dumped into the world's oceans every year, estimates suggest. Three of the world's ten rivers which carry $90 \%$ of plastic to the world's oceans are in India-the Indus, the Ganga and the Brahmaputra, according to an October 2017 article in Environmental Science and Technology, a global journal. As of initial months of 2018 most of Indian states has banned plastics but it continues to choke waterways, landfills and air. Chocking of drainage system is leading to water logging issues in all major cities of India; Chennai, Delhi, Mumbai 
or Kolkata. The coastal cities are more vulnerable as they faces water upsurge on a frequent basis during heavy monsoonal rainfall, depression, tidal patterns, ocean circulations, wind movements as well as blockage of all water outlets due to plastic clogging. The need of the hour is to be more organized with respect to sustainable town planning and take the movement against plastics to the grassroots of the society to generate collective consciousness. Voice of Environment; a Guwahati based $\mathrm{NGO}$ is carrying forward a nationwide campaign to ban plastics. Recent awareness campaigns have been organized in famous Maa Kamakhya Temple in Guwahati, Assam in India's northeast to make the premises completely plastic free. Similar such activities are also carried out in Shri Basistha Temple and other historic and religious monuments. We need to create model campaigns against plastic pollution at all levels of society. If the secretariats, government offices and universities go plastic free, automatically a positive message would be carried forward across all sectors. It is important to understand Plastic Pollution from a local perspective as well. General awareness regarding plastic pollution is poor. Our heavy dependency on plastic and all its' derivatives is a major hindrance to curbing the menace. With the exception of a small population of environmentally conscious individuals and organizations, public concern towards the issue is largely laced with apathy and indifference; a report from The Better India quotes. India aims to beat plastic pollution by 2022 . Initiatives such as plastic clean-up drives across public spaces, national forests and biosphere reserves along with simultaneous beach clean-up activities are in the pipeline. The pledge also includes transforming 100 monuments across the country into plastic and litter-free zones. Even the Tourism Ministry has risen to the occasion by pledging to avoid plastic straws at public places. Initiatives are on at the local levels by several NGOs across the country. Youth organizations such as Voice of Environment based in Guwahati, Assam-India and its' pan India team vows to make our planet beautiful again. Together, We Can and Will make the planet plastic free! 